\title{
Delayed Gastric Emptying of Semi-solid diets in Patients with Chagasic Megaesophagus
}

\author{
Decio Chinzon, Tomas Navarro-Rodriguez, Karine Dal-Paz, Ricardo Anuar Dib, \\ Joaquim Prado Pinto de Moraes-Filho
}

University of Sao Paulo School of Medicine, Department of Gastroenterology, São Paulo, Brazil

OBJECTIVE: To measure the time to gastric emptying of a semi-solid diet in individuals with Chagasic megaesophagus, in comparison with a non-Chagasic control group.

METHOD: The time to gastric emptying of a semi-solid diet was assessed via ultrasonography in 28 patients with Chagasic megaesophagus (grades I, II, and III) and compared to that of a control group $(n=15)$. After measurement of antral diameter under fasting conditions, $400 \mathrm{~mL}$ of a semi-solid diet were administered and consecutive measurements were performed every $30 \mathrm{~min}$.

RESULTS: The duration of dysphagia was significantly lower in patients with megaesophagus grade I than in those with grades II or III. The time to gastric emptying was significantly increased in the megaesophagus group compared to the control group. The means of antral areas measured under fasting conditions and after maximal antral distension did not differ between the megaesophagus and control groups.

CONCLUSION: The time to gastric emptying of a semi-solid diet was significantly greater in patients with Chagasic megaesophagus than in controls. The delay did not depend on the extent of dilatation of the megaesophagus or the duration of dysphagia.

KEYWORDS: Gastric emptying; Chagasic megaesophagus; Dysphagia.

Chinzon D, Navarro-Rodriguez T, Dal-Paz K, Dib RA, Moraes-Filho JPP. Delayed Gastric Emptying of Semi-solid diets in Patients with Chagasic Megaesophagus. MEDICALEXPRESS. 2014 Oct;1(5):271-274.

Received for publication on July 25 2014; First review completed on August 5 2014; Accepted for publication on September 62014

Email: tnavarro@usp.br

\section{INTRODUCTION}

Chagas disease is a major public health problem that is largely restricted to South America, ${ }^{1,2}$ where it affects 15 million individuals. The combined annual incidence is 42,000 cases in 21 countries $^{3}$. In Latin America alone a cost of 6.5 billion US dollars per year has been estimated. ${ }^{4}$ In Brazil, the disease kills approximately 5,000 people per year. ${ }^{5}$

Chagas disease is currently ubiquitous because of alterations in the social patterns of many countries caused principally by migration from rural areas to cities and to North American countries. ${ }^{4,6}$ In the southern United States, the disease is considered emergent, ${ }^{4}$ in a non-endemic form. The condition can be transmitted by transfusion of blood and blood derivatives, organ transplantation, and orally; the disease may also be congenital. ${ }^{7,8,9}$ About $30 \%$ of infected individuals develop the chronic symptomatic form of the disease, usually decades after the initial infection. ${ }^{3,4,10}$ One complication of the disease is alteration of the upper gastrointestinal tract caused by destruction of the myenteric plexus ${ }^{11}$ This results in delayed esophageal emptying secondary to dysfunction of the lower esophageal sphincter

DOI: 10.5935/MedicalExpress.2014.05.11 and esophageal body. Food material is retained, triggering esophageal dilatation. The prevalence of megaesophagus in patients chronically infected with Trypanosoma cruzi, the protozoan causing Chagas disease, varies from $5-18 \%{ }^{2,12}$

Megaesophagus is defined as a failure of the esophagogastric sphincter to relax upon swallowing, and failure of the esophageal body to contract appropriately because of degeneration of ganglion cells in the wall of that organ caused by Trypanosoma cruzi infection. Thus, the lower portion of the esophagus becomes abnormally enlarged. According to the classification proposed by Rezende, ${ }^{13}$ in recumbent patients with megaesophagus grade $\mathrm{I}$, peristalsis fails to clear a barium bolus appropriately from the esophagus. Esophageal transit is slow, and low-grade retention of the barium column is evident. In grade II recumbent patients, peristalsis fails to clear a barium bolus appropriately from the esophagus, and a low-to-moderately dilated esophagus exhibiting retention of the barium column and tertiary contractions is frequently seen. The lower esophageal sphincter pressure may be high. In grade III recumbent patients, peristalsis fails to clear a barium bolus appropriately from the esophagus, and very pronounced dilatation of the esophagus, with retention of most of the barium column, is evident. Esophageal motor activity, although present, is much reduced. In a grade IV recumbent 


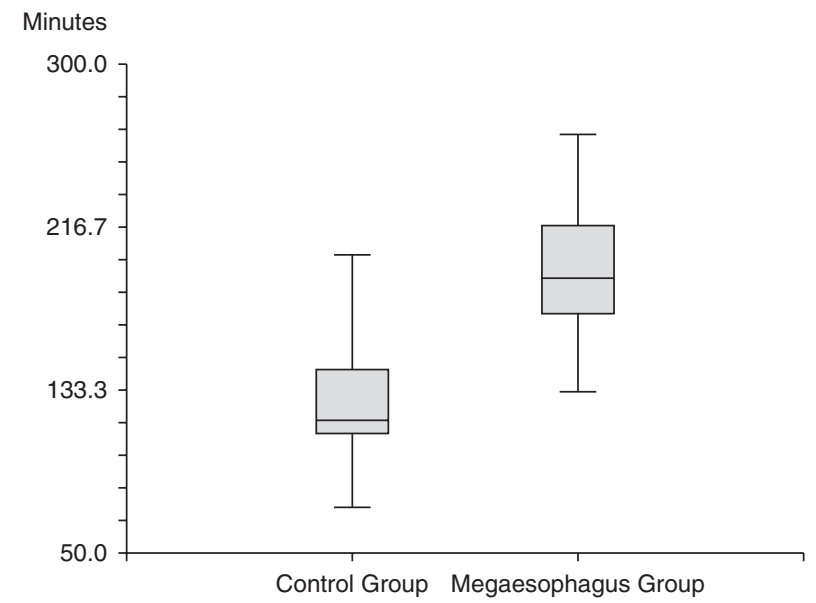

Figure 1 - Graphic representation of gastric emptying $(p<0.001)$.

patient, peristalsis fails to clear a barium bolus appropriately from the esophagus, and the organ is greatly dilated with extensive retention of contrast. The esophagus may exhibit tortuosity, and is sometimes superimposed on the diaphragm. Peristaltic activity is absent.

The main clinical manifestations of individuals with megaesophagus are dysphagia, odynophagia, and weight loss. ${ }^{14,15}$ Dysphagia is the most common symptom, occurring when either solid or liquid food is taken. ${ }^{16}$

Studies on impairment of gastric emptying in Chagasic megaesophagus patients have revealed delayed emptying following consumption of solid ${ }^{17}$ and liquid foods. ${ }^{18,19}$ However, semi-solid diets, which are consumed more frequently by individuals with megaesophagus, have not been tested. This diet is selected because of dysphagia, which is a frequent symptom. ${ }^{16,20}$

The objective of this study was to evaluate the time to gastric emptying after consumption of a semi-solid diet in individuals with Chagasic megaesophagus as compared to a non-Chagasic control group.

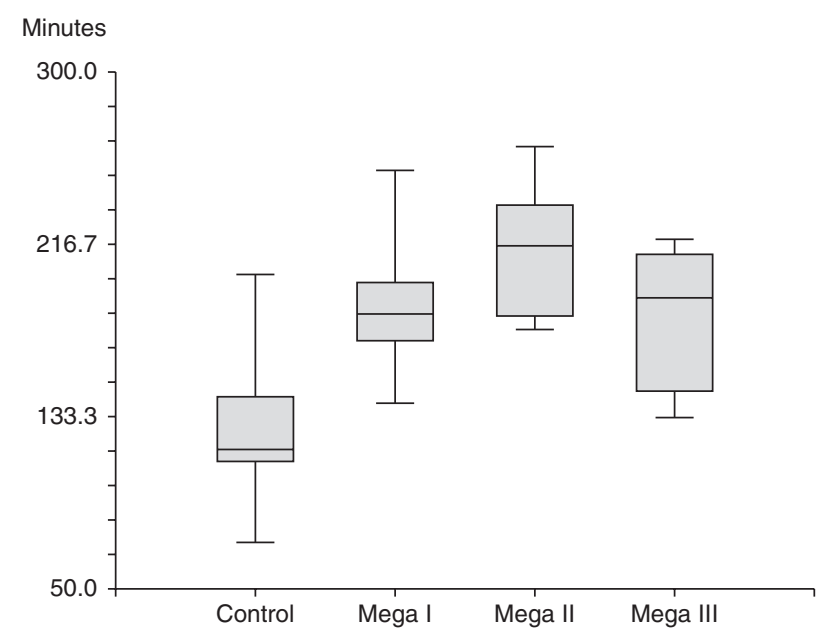

Figure 2 - Graphic representation of gastric emptying among different grades of megaesophagus and control groups $(p<0.001)$.

\section{METHOD}

Forty three patients were included in this study. They were divided into two groups: control (C: 15 patients) and megaesophagus (M: 28 patients).

The exclusion criteria were: age $<16$ and $>65$ years; a clinical history of a previous esophageal condition, a previous surgical procedure conducted in the esophagealduodenal region; the use of pro-kinetic or anti-spasmodic drugs within 2 weeks prior to evaluation; the presence of any comorbidity affecting digestive motility (diabetes, thyroid disease, progressive systemic sclerosis, and/or neuropathy); the presence of neoplasia and/or a concomitant megacolon.

The control group consisted of 15 patients that did not present with severe digestive complaints; with no radiological and/or endoscopic esophageal, gastric, and/or duodenal alterations; no positive serological reactions for Chagas disease; no parasites in stool.

The megaesophagus group consisted of 28 patients who presented with positive serological results for Chagas disease and megaesophagus, diagnosed via contrastenhanced radiological assessment of the esophagus. Observed dilatation was grade I (10 patients), grade II (eight patients) and grade III (ten patients).

This study was approved by the ethical and scientific committees of the Department of Gastroenterology (Clinical Gastroenterology) in the School of Medicine of the University of Sao Paulo. Prior to enrolment, all patients were informed of the nature of the study and signed a free and informed consent form.

The semi-solid diet consisted of $95 \mathrm{~g}$ of cooked potato, $10 \mathrm{~g}$ of margarine, $300 \mathrm{~mL}$ of milk, and $70 \mathrm{~g}$ of "Protein Plus" (proteins: $5.6 \mathrm{~g}$; lipids: $5.6 \mathrm{~g}$; carbohydrates: $20.8 \mathrm{~g}$; linoleic acid: $2.0 \mathrm{~g}$; [caloric value: $156.0 \mathrm{kCal}$ and osmolarity $330 \mathrm{mOsm} / \mathrm{kg}])$. The final composition was $28.62 \mathrm{~g}(15 \%)$ protein, $55.06 \mathrm{~g}(40 \%)$ lipid, and $111.41 \mathrm{~g} \mathrm{(45 \% )}$ carbohydrate. All ingredients were homogenized in a blender for about 3 min until a semi-solid consistency was attained; the final volume was $400 \mathrm{~mL}$, the osmolarity $450 \mathrm{mOsm}$, and the total caloric value $1,055 \mathrm{kCal}$.

Gastric emptying time was studied using the method of Bolondi et al., ${ }^{21}$ which employs images obtained via realtime ultrasonography. All ultrasonographic assessments were performed using a Shimatzu model SDU 700. The time to gastric emptying was measured via consecutive ultrasonographic assessments of the antral area at constant time intervals. Subsequently, emptying curves were drawn.

To calculate the antral area, we considered the area corresponding to a sagittal plane crossing the upper mesenteric vein and the aorta, represented ultrasonographically by (approximately) an ellipse. Images were obtained using a $3.5-\mathrm{MHz}$ transducer placed vertically on the epigastric region, with patients in the orthostatic position. To calculate the antral area (As), the anteroposterior (A) and craniocaudal (B) diameters were estimated, and the following formula applied: $\mathrm{As}=(\pi \mathrm{A} \mathrm{B}) / 4$.

Initial assessment $(t=-1)$ was performed on an empty stomach, and it formed the basis of subsequent calculations. Next, $400 \mathrm{~mL}$ of the semi-solid diet were administered through $50-\mathrm{mL}$ syringes over $5 \mathrm{~min}$, via a nasogastric tube (diameter: $6 \mathrm{~mm}$ ), with the distal extremity located $55 \mathrm{~cm}$ from the naris and the fluoroscopy probe positioned in the middle of the stomach. During this procedure, any 
obstruction observed in any patient (of either the control or megaesophagus groups) was noted.

Immediately after administration of the meal, the nasogastric tube was removed and the antral area again measured ultrasonographically. This represented a full stomach $(t=0)$. Subsequently, measurements were performed every $30 \mathrm{~min}(\mathrm{t} 1=30, \mathrm{t} 2=60, \mathrm{t} 3=90, \mathrm{tn}=\mathrm{x})$, until the final antral area attained the size of the initial area (measured at $t=-1$ ). Next, we drew gastric emptying curves by joining the points corresponding to the various measurements.

Data were analyzed using the non-parametric KruskalWallis test, the Mann-Whitney U test, Wilcoxon's test, and Pearson's chi-squared test. The level of significance was set at $\mathrm{p}<0.005$.

\section{RESULTS}

The times to gastric emptying were $129.0 \pm 29.6 \mathrm{~min}$ in control individuals and $192.9 \pm 32.7 \mathrm{~min}$ in the megaesophagus group. The difference between the two groups was statistically significant ( $\mathrm{p}<0.001$ ), as shown in Figure 1.

When the M group data were stratified by megaesophagus grade, the times to emptying in grade I patients were $186.0 \pm 26.2 \mathrm{~min}, 214.6 \pm 30.6 \mathrm{~min}$ in grade II patients, and $182.4 \pm 34.6 \mathrm{~min}$ in grade III patients, as shown in Figure 2. These times did not differ significantly $(p>0.05)$.

The initial mean antral areas obtained under fasting conditions were $6.16 \pm 2.04$ and $5.48 \pm 1.42 \mathrm{~cm}^{2}$ in the $C$ and $\mathrm{M}$ groups, respectively, and did not differ significantly. In the $\mathrm{M}$ group, the initial areas in those of grades I, II, and III were $5.38 \pm 1.27 \mathrm{~cm}^{2}, 5.20 \pm 1.65 \mathrm{~cm}^{2}$, and $5.80 \pm 1.45 \mathrm{~cm}^{2}$, respectively, and did not differ significantly. Antral measurements obtained from stomachs that were maximally dilated after ingestion of the test meal were similar between the $C\left(17.40 \pm 6.67 \mathrm{~cm}^{2}\right)$ and $M\left(20.82 \pm 6.03 \mathrm{~cm}^{2}\right)$ groups $(\mathrm{p}=0.07)$. In the Chagasic sub-groups, the figures for those in grades I, II, and II were $24.66 \pm 7.71 \mathrm{~cm}^{2}, 19.59 \pm 3.38 \mathrm{~cm}^{2}$, and $17.97 \pm 3.73 \mathrm{~cm}^{2}$, respectively, and did not differ significantly $(\mathrm{p}=0.08)$.

\section{DISCUSSION}

In the present study, the time to gastric emptying was significantly higher in the $M$ than in the $C$ group. When the Chagasic group was analyzed by megaesophagus grade, all of the patients of subgroups I, II, and III differed significantly from the controls. This is significant, because although it is known that the grade of esophageal dilatation is proportional to the degree of denervation, our results show that this is not associated with stomach properties. Thus, the time to gastric emptying was delayed regardless of megaesophagus grade.

A hypostenic syndrome was evident in all patients with megaesophagus grades II and III and in 50\% of those with grade I.

Any physiopathological interpretation of dyspeptic manifestations is difficult, because, in addition to the megaesophagus per se, functional motor alterations may also be present. These can be accompanied by the hypostenic syndrome and other clinical manifestations. ${ }^{22}$

It is possible, however, that delayed gastric emptying was one factor contributing to the morbidity of our patients. Dysphagia, on the other hand, is directly associated with the presence of achalasia, ${ }^{23}$ and the clinical histories thereof are longer in patients with greater esophageal dilatation, as in grades II and III. This fact suggests that the duration of relevant history is associated with the degree of esophageal dilatation found in such patients, but not with the observed gastric alterations.

The results of the present study confirm, with the use of a semi-solid diet, the previous data of Lopasso ${ }^{17}$ (obtained using solid foods), indicating that delayed gastric emptying is secondary to the reduced integrity of the enteric nervous system in the stomach of Chagas disease patients. ${ }^{11}$ This would decrease contractile frequency and/or strength because of a lack of motor co-ordination of the stomach and antrum, generated in part by a reflex triggered by organ distension. $^{24,25}$

Although we did not study the topic, it is interesting to observe that a degree of achalasia of the pylorum may contribute to the delayed gastric emptying found in individuals with Chagasic megaesophagus. ${ }^{26}$

The maximal antral areas obtained after administration of the test meal, and those obtained under initial fasting conditions, were similar in controls and Chagasic patients. These findings suggest that, in agreement with the literature, megastria is uncommon, and that the elasticity of the stomach is preserved, even in patients with denervation secondary to trypanosomiasis.

In conclusion, the time to gastric emptying after administration of a semi-solid diet was significantly delayed in patients with Chagasic megaesophagus, compared to control individuals without severe digestive disease, and was independent of megaesophagus grade (assessed through dilatation), duration of relevant history, and stomach distensibility.

\section{RESUMO}

OBJETIVO: Medir o tempo de esvaziamento gástrico de uma dieta semisólida em indivíduos com megaesôfago chagásico, em comparação com um grupo controle não-chagásico.

MÉTODO: O tempo necessário para o esvaziamento gástrico de uma dieta semi-sólida foi avaliada por meio de ultrassonografia, em 28 pacientes com megaesôfago Chagásico (graus I, II, e III) e comparado com o de um grupo de controle $(n=15)$. Após medida do diâmetro antral em jejum, $400 \mathrm{~mL}$ de uma dieta semi-sólida foram administradas e medidas consecutivas foram realizadas a cada $30 \mathrm{~min}$.

RESULTADOS: A duração da disfagia foi significativamente menor nos pacientes com megaesôfago grau I do que naqueles com graus II ou III. O tempo de esvaziamento gástrico foi significativamente aumentado no grupo megaesôfago em comparação com o grupo de controle. As médias de áreas antrais medidas em jejum e após a distensão antral máxima não diferiram entre os grupos megaesôfago e controle.

CONCLUSÃO: O tempo de esvaziamento gástrico de uma dieta semi-sólida foi significativamente maior em pacientes com megaesôfago chagásico que nos controles. $O$ atraso não depende da extensão da dilatação do megaesôfago ou da duração clínica da disfagia.

\section{REFERENCES}

1. Rezende JM, Meneghelli UG. A visita ao Brasil de Franz J. Ingelfinger e sua participação na divulgação dos conhecimentos sobre o megaesôfago chagásico. Rev Ass Med Bras. 2001;47(3):262-8.

2. Kamiji MM, Oliveira RB. O perfil dos portadores de doença de Chagas, com ênfase na forma digestiva, em hospital terciário de Ribeirão Preto, SP. Rev Soc Bras Med Trop. 2005;38(4):305-9.

3. Guhl F, Lazdins-Helds JK. Reporte sobre la enfermedad de Chagas. Grupo de trabajo científico 17-20 de abril de 2005 [Web site]. Buenos Aires, Argentina. Available at: http://www.who.int/tdr/ publications/ publications/pdf/swg_chagas.pdf. Accessed September 2, 2008. 
4. Hanford EJ, Zhan FB, Lu Y, Giordano A. Chagas disease in Texas: Recognizing the significance and implications of evidence in the literature. Soc Sci \& Med. 2007;65(1):60-79.

5. Momen H. Emerging Infectious Diseases-Brazil. Emerging Infectious Diseases National Center for Infectious Diseases [Web site Periodic]. 1998;4(1), Available at: URL:http:/ /www.cdc.gov/ncidod/eid/vol4no1/ momen.htm. Accessed August 27, 2008.

6. Wanderley DM, Correa FM. Epidemiology of Chagas' heart disease. Sao Paulo Med J. 1995;113(2):742-9.

7. Grant IH, Gold JW, Wittner M, Tanowitz HB, Nathan C, Mayer K, et al. Transfusion-associated acute Chagas disease acquired in the United States. Ann Intern Med. 1989;111(10):849-51.

8. WHO (Word Health Organization). Technical Report Series 905. Control of Chagas disease. Geneva 2002.

9. Nowicki MJ, Chinchilla C, Corado L, Matsuoka L, Selby R, Steurer F, et al. Prevalence of antibodies to Trypanosoma cruzi among solid organ donors in Southern California: a population at risk. Transplantation. 2006;81(3):477-9.

10. CDC (Centers for Disease Control and Prevention). Blood Donor Screening for Chagas Disease in United States, 2006-2007. Available at: http: / / www.cdc.gov/mmwR/preview/mmwrhtml/mm5607a2.htm. Accessed September 2, 2008.

11. Tanowitz HB, Kirchhoff LV, Simon D, Morris AS, Weiss LM, Witfner M. Chagas'disease. Clin Microb Rev. 1992;5(4):400-19.

12. Meneghelli UG, Peria FM, Darezzo FMR, Almeida FH, Rodrigues CM, Aprile LRO, et al. Clinical, radiographic, and manometric evolution of esophageal involvement by Chagas disease. Dysphagia. 2005;20:40-5.

13. Rezende JM. Classificação radiológica do megaesôfago. Rev Goiana Méd. 1982;28(2):187-91.

14. Atias A. A case of congenital chagasic megaesophagus: evolution until death caused by esophageal neoplasm, at 27 years of age. Rev Med Chil. 1994;122(3):319-32
15. Brücher BL, Stein HJ, Bartels H, Feussner H, Siewert JR. Achalasia and esophageal cancer: incidence, prevalence, and prognosis. World J Surg. 2001;25(6):745-9.

16. Oliveira RB, Troncon LE, Dantas RO, Menghelli UG. Gastrointestinal manifestations of Chagas disease. Am J Gastroenterol. 1998;93(6):884-9.

17. Lopasso FP, Meneguetti JC, Bruno de Mello J, Gama-Rodrigues J, Raia AA. Gastric emptying in duodenal ulcer patients before and after proximal gastric vagotomy. Use of solid, digestible particles labelled with 99mTc. Rev Assoc Med Bras. 1983;29(1-2):10-3.

18. Oliveira RB, Troncon LEA, Meneguelli UG, Padovan W, Dantas RO, Godoy RA. Impaired gastric accomodation to distension and rapid gastric emptying in patients with Chagas' disease. Dig Dis Sci. 1980;25(10):790-4

19. Troncon LE, Iazigi N. Scintigraphic study of the gastrointestinal transit of a liquid meal in patients with chronic Chagas disease. Braz J Med Biol Res. 1992;25(2):145-8.

20. Rezende-Filho J, Rezende JM, Melo JRC. Electrogastrography in patients with Chagas disease. Dig Dis Sci. 2005;50(10):1882-8.

21. Bolondi L, Bortolotti M, Santi V, Calletti T, Gaiani S, Labò G. Measurement of gastric emptying time by real time ultrasonography. Gastroenterol. 1985;89(4):752-9.

22. Moraes-Filho JPP. Doenças funcionais do aparelho digestivo: a importância dos distúrbios emocionais na gênese de sintomas. Rev Bras Med. 1994;51:1395-404.

23. Dantas RO. Dysphagia in patients with Chagas disease. Dysphagia. 1998;13(1):53-7.

24. Dubois A. The stomach. In: Christensen J, Wingate D. A Guide to Gastrointestinal Motility. Londres: Wright, PSG, 1983; p. 101-27.

25. Heading RC. Methods based on gastric intubation; $X$-ray and ultrasound imaging methods; indirect techniques. In: Akkermans LMA, Johnson AG, Read NW. Gastric and Gastroduodenal Motility. New York, Praeger Publishers. 1984; 131

26. Pinotti HW, Felix VN, Zilberstein B, Cecconello I. Surgical complications of Chagas disease: megaesophagus, achalasia of the pylorus, and cholelithiasis. World J Surg. 1991;15(2):198-204. 